\title{
Immigration Detention and Juxtaposed Border Controls on the French North Coast
}

"I'm glad I don't work at Calais any more. It's a young man's game. All that chasing people, forcing them out of the vans." (Immigration Officer, Eurostar Terminal, Paris, Gare du Nord, June 2018).

\begin{abstract}
In this article, I build on criminological accounts of immigration detention by examining British short-term holding facilities located on French territory in the ports of Calais and Dunkerque and the policies and treaties which govern them. For a number of reasons, including barriers to research access, their legal complexity, modest size and nature, these institutions have received little empirical or theoretical scrutiny. Yet, as I shall demonstrate through an analysis of a range of published material from Parliamentary debates, government and non-governmental agencies, the media and the internet, as well as observations of the sites themselves and figures about them, these banal, bureaucratic sites of temporary custody play an important role in upholding the more familiar border spectacle of the region.
\end{abstract}

\section{Key words}

Immigration detention, Calais, administrative power, border spectacle, juxtaposed controls, sovereignty

\section{Introduction}

In this paper, I contribute to criminological understanding of immigration detention as well as to the interdisciplinary body of work on the Franco-British border by examining the four British Short-term holding facilities (SHTFs) that operate in Calais and Dunkerque under juxtaposed controls. ${ }^{1}$ Little more than a series of nearly empty waiting rooms, these mundane buildings, which are out of sight and hard to access, hold people briefly to facilitate their immigration or asylum processing that will occur elsewhere. For nearly everyone the outcome of detention in these sites is the same: Irregular migrants and foreign nationals denied entry are placed here for a few hours by UK Border Force, before they are handed over to the French Polices Aux Frontières (PAF) for management. Unless they are found to have no right to be on French territory, they will be immediately released beyond the juxtaposed control area of the port. Under the terms of the Dublin Convention, ${ }^{2}$ asylum seekers face

\footnotetext{
${ }^{1}$ According to a Home Affairs Committee report in 2016, Border Force operated "juxtaposed controls at seven locations in France and Belgium:

- $\quad$ Calais and Dunkirk for ferry passengers and vehicles;

- Coquelles for vehicles using the Channel Tunnel; and

- Paris, Brussels, Lille and Calais-Fréthun for Eurostar foot passengers." (2016: 7).

This paper examines only with the sites of detention in Northern France (for more details see Vine, 2013 and Clayton, 2010).

2 For more on how this Convention concerning the management of asylum seekers impacts immigration detention please see: $X$ et al, 2020; Basilien-Gainche, 2015; Costello and Mouzourakis, 2016. Space constraints prevent further discussion of this legal arrangement here.
} 
similar consequences. Some will be taken by the PAF to the nearby French detention centre -- the Coquelles Centre de Rétention Administrative - while others are released onto the streets of Calais. Still others, found in (criminal) violation of a French deportation order, may be taken to a nearby gaol (xx et al 2016; 2020).

So far, there is no academic scholarship on short term holding facilities wherever they are located. Researchers interested in immigration detention have tended to focus on longer-term sites of confinement (see for example, XX, 2014; Mainwearing and Silverman, 2017), whereas those who study the border zone itself have, quite understandably, concentrated on more visible and violent forms of immigration enforcement (see, for example, Jones, 2017; De Genova, 2002; 2013; Brown, 2010). Still others have examined the experiences of those who cross or attempt to cross such barriers (Sanchez, 2016; Andersson, 2014). While, finally, there is also a considerable body of research which examines how the policing of migration shapes and reshapes territorial and other forms of border control (van der Woude, 2018; Gundhus and Franko, 2016; Barker, 2017).

Hidden within a more familiar, muscular (Katz, 2007), border regime that deploys force, technology, and barbed wire to prevent entry, these holding facilities illuminate some of the more mundane ways in which states (and their private subcontractors) seek to manage migration. Coercion, in these unremarkable spaces is evident in out of date guidance on ragged notice boards, rather than in the deliberate infliction of physical pain. It appears in the British helplines that connect people in France to groups who cannot assist because they operate in a different jurisdiction; it is present in the juice boxes and flavoured long-life croissants that are offered to those who may have been cooped up in unsafe and unsanitary spaces for hours. It can more readily be gleaned from official descriptions of "poorly ventilated holding rooms with squat toilets in the corner" (HMIP and CGLPL, 2016a: 7); or in the always present potential use of force by custodial staff, even if this form of coercion the monitors write, "is only used as a last resort and for legitimate reasons" (ibid: 9). The border may well be secured, visible, and violent in the environs of Calais by police wielding batons (Human Rights Watch, 2017), and by the geographical concentration of vulnerable people into unsafe and unsanitary encampments surrounding the town (Bhatia, 2018; Babels Collective, 2017; Ibrahim and Howarth, 2018; Hicks and Mallet, 2019), but as these short-term holding facilities demonstrate, border control operates in quieter, less dramatic ways as well, without comment or critique (Mountz, 2015; Yuval-Davis et al, 2019).

The article starts with an account of offshore border controls, before turning to the legal framework of juxtaposed controls within which the sites of detention on the French North Coast sit. ${ }^{3}$ I then describe the short-term holding facilities and their daily regimes. As I will demonstrate, these sites of confinement resist simple explanation. Expansive, yet precarious; entrenched, yet volatile; always open, yet frequently empty; they sit at the intersection of an array of local, national,

\footnotetext{
${ }^{3}$ For accounts of other forms of binational agreement that also result in detention and deportation, see Vrabiescu, 2019 on arrangements between France and Romania, and Barbero, 2018 for an account of practices at the Franco-Spanish border.
} 
international and corporate interests and concomitant legal arrangements. While certainly those held within them (however briefly) are coerced, these are, above all, sites of administrative convenience for the state. Contracted out to the private sector, they are buffer zones, holding cells for the unwanted, who will be moved on, before any claim (on us) can be made. In so doing, they effectively and without fanfare render "invisible and inaudible" those within (Isin and Rygiel, 2007: 184), while efficiently connecting different legal systems which facilitate the work of coercive state and private sector actors.

\section{Offshoring and Juxtaposed border controls.}

States around the globe have, for many years, used offshore sites of detention as a strategy of border control. Many prefer islands (Mountz, 2011; 2015), although often anywhere outside their sovereign territory will do (Gibney, 2006; xx, 2017). Offshore sites are usually chosen, Alison Mountz (2011) reminds us, for their legal exceptionalism (Agamben, 2005). In these terms, it is worth remembering that the original detention site on Guantánamo Bay, Cuba, was built by the US to house irregular immigrants away from the US mainland, well before it became part of the 'war on terror'. Whereas for a number of years, the European Union has suggested opening facilities in North Africa, so far, they have settled on legal agreements with Turkey and Libya to return third country nationals. Out of sight, and typically in countries of the 'global south', where financial and legal arrangements keep foreigners well away from northern borders, these places illuminate the enduring ties between sovereign and biopolitical power, and the importance of teritory (Foucault, 2004; 2009). In them, the state identifies and controls unwanted populations, managing their mobility and access to territory (Aradau and Tobias 2010; Walters, 2015).

Calais and Dunkerque do not quite fit the island model, even though for Britain at least, they have the same effect. In part, their distinctiveness rests on their location. Most obviously, despite being located 'offshore', from a British perspective, they are 'onshore' for France. Also, and unlike the detention centres transacted by the 'Northern penal state' (Aas, 2013), which are located outside the legal framework of the detaining power and usually within territories in the global south, the British short-term holding facilities on the French North coast are governed and regulated through 'juxtaposed controls' (Vine, 2013), shared between two equally powerful nations. They are not sites of 'exception' (Agamben, 2005), but rather are subject to the same set of human rights frameworks that both countries have ratified and follow. In these sites of temporary confinement, France and Britain share power, however uneasily and incompletely.

Juxtaposed controls have existed between France and the UK since 1994, when they were introduced "to speed up entry and exit procedures on the Channel Tunnel route" (Vine, 2013: 3). Created by the Sangatte Protocol of 1991, these checkpoints were expanded in 2000 by 'An additional protocol to the Sangatte Protocol' that included all the main train stations on the Eurostar route from 2001. In 2003, the 
Treaty of Touquet, ${ }^{4}$ which was put into effect in Britain by the Nationality, Immigration and Asylum Act 2002 (Juxtaposed Controls) Order 2003 (Clayton, 2010; Schuster, 2003; Ryan, 2004) added ferry ports to the list of checkpoints. In 2004 the holding zone at Calais Tourist was constructed (HMIP, 2006), while in 2007 an amended Sangatte Agreement ${ }^{5}$ created the detention sites at Coquelles (near the entrance to the Eurostar).

Under the terms of these Treaties, foreign border authorities and police in the areas governed by juxtaposed controls wield the same prerogatives as those they possess in their home country. In practice, what this means is that, within these geographical spaces, the British Border Force can stop and search individuals and freight vehicles while they are still on French soil, while their French Polices Aux Frontières colleagues do the same on British territory; anyone found with irregular immigration status or who claims asylum, as well as people who are suspected of serious criminal or terrorist offences (or indeed of being a victim of modern slavery) may be briefly detained in short-term holding facilities for up to 24 hours, or exceptionally, for 48 hours. Since 2010, the British and French have run a joint 'operational coordination centre' in Calais to share intelligence. Finally, the UK also provides extensive funds for new technology and fencing around the border sites in France. $^{6}$

While juxtaposed controls are governed by the Treaties between France and Britain, they have roots in the 1985 Schengen Agreement ${ }^{7}$ which was originally agreed by just ten EU member states (including France). It took another decade and a new Convention ${ }^{8}$, for Schengen to be incorporated into the main body of EU law, and even then, Britain never signed on (Walters, 2002). Although designed to remove internal border checks among signatory states, Schengen did not end all surveillance of mobility. Rather, as Barbero (2018:1) suggests, it facilitated "a police managed model of internal borders" which blurred the boundaries between immigration and criminal control (van der Woude and van der Leun, 2017; van de Woude, 2018). It similarly elided administrative law and punishment by establishing carrier penalties for transporting irregular migrants, (Delmas-Marty and Teitgen-Colly, 1992: 8; Scholten, 2015; Bloom and Risse, 2014). These administrative penalties which were mirrored in British law -- first by the Immigration (Carriers' Liability) Act 1987, ${ }^{9}$ then by the 1999 Immigration and Asylum Act ${ }^{10}$-- lead directly to the system of juxtaposed controls.

\footnotetext{
${ }^{4}$ http://www.official- documents.gov.uk/document/cm66/6604/6604.pdf

${ }^{5}$ http://www.official-documents.gov.uk/document/cm72/7219/7219.pdf

${ }^{6}$ Created in 2010 at the Evian Summit

${ }^{7}$ https://eur-lex.europa.eu/legal-content/EN/ALL/?uri=CELEX:42000A0922(01)

${ }^{8}$ https://eur-lex.europa.eu/legal-content/EN/ALL/?uri=CELEX:42000A0922(02)

${ }^{9}$ Which introduced a fixed penalty charge of $£ 1000$ "for each passenger who failed to produce a valid travel document to the immigration officer on arrival" (Scholten, 2015: 86)

10 Which established additional civil penalties for carriers at a fixed rate of $£ 2000$ per person which, "applied to all vehicles, ships or aircraft bringing clandestine entrants to the UK and also, from, 2001 to rail freight transporters and Eurotunnel freight shuttle wagons" (Scholten, 2015: 86)
} 
Over a period of four months commencing in late 2001, after the International Committee of the Red Cross opened a camp for asylum seekers near the French entrance to the Channel Tunnel in Sangatte, the British government used this legislative power to institute a series of fines against Eurotunnel (freight and passenger), which eventually lead to estimated losses of $f 132$ million (Scholten, 2015: 237). ${ }^{11}$ Whereas the 1991 Sangatte Protocol and the additional protocol to it that was signed in May 2000 had created immigration check points at Coquelles and at the Eurostar Terminals, which allowed for a period of 48 hours of detention, it was the Treaty of Touquet, signed in February 2003, which expanded juxtaposed controls and led to further detention sites in Dunkerque and Calais.

Notwithstanding the inability of any state to eradicate unauthorized entry, in French Parliamentary debates over the Treaty of Touquet in 2003, members of the National Assembly emphasized the importance of maintaining the Western border of the Schengen Zone, casting border control in a heroic narrative of building and securing a particular vision of Europe. ${ }^{12}$ The interests of Britain and France were considered to be complementary and, in stark contrast to matters at the time of writing, equally disposed towards a European politics of cooperation. As M. Renaud Donnedieu de Vabres, Minister for Neiully-sur-Seine, under Jacques Chirac's UMP government, put it:

"The Touquet Treaty is essentially a technical agreement, but also marks the common will of France and the United Kingdom to co-operate in the fight against illegal immigration, and could be a prelude to a European asylum and social policy, that is more integrated immigration, and based on harmonized legislation."

"At the dawn of this year of commemoration of the entente cordiale," he went on, optimistically, "one can imagine that one day the protection of the maritime space of the English Channel and the North Sea will be carried out by fleets flying the Franco-British flag." The only 'problem' that remained, he joked, was what to do about Home Office workers in turbans, who, as civil servants, under French law, would not be permitted to display such religious artefacts at work. ${ }^{13}$ From across

\footnotetext{
11 In 2003, Eurotunnel commenced proceedings against the French and British governments at the International Tribunal of Arbitration, claiming that neither government had done enough to secure the Channel Tunnel, four years later the Tribunal partially ruled in its favour. In 2008 the French government paid $\mathrm{f} 24$ million in damages and the following year the British government paid it $f 8$ million (Audit, 2008; Scholten, 2015: 234 -235; see also The Channel Tunnel Group Ltd and FranceManche, Sa v. United Kingdom and France, partial award on Jurisdiction, decision of 30.01.2007 (Available at: https://pcacases.com/web/sendAttach/487). ${ }^{12} \mathrm{http}: / /$ www.assemblee-nationale.fr/12/cra/2003-2004/108.asp

13 "Le traité du Touquet est un accord essentiellement technique, mais marque également la volonté commune de la France et du Royaume-Uni de coopérer dans la lutte contre l'immigration clandestine, et pourrait préluder à une politique européenne de l'asile et de l'immigration plus intégrée, et fondée sur des législations harmonisées... A l'aube de cette année de commémoration de l'entente cordiale, on peut imaginer qu'un jour, la protection de l'espace maritime de la Manche et de la mer du Nord soit effectuée par des flottilles battant pavillon franco-britannique... que faire des fonctionnaires britanniques qui, travaillant sur notre territoire, porteront le turban, ainsi qu'il est permis au Royaume-Uni?"
} 
the political divide, Donnedieu's communist colleague, Minister for the Somme, Maxime Gremetz agreed, noting with approval, that while the Treaty of Touquet was only a bilateral agreement (with Britain) it represented the first step towards a shared European politics of migration. ${ }^{14}$

In contrast to the optimism of their French counterparts, British politicians were far more cautious about ceding sovereignty. Members from all parties became particularly exercised, for example, about hosting armed French police in Kent, alarmed about the symbolic as well as practical dangers of permitting foreign officers to bear arms, on British soil, given that most British police officers do not carry guns. When the Nationality, Immigration and Asylum Act 2002 (Juxtaposed Controls) Order 2003 was debated in the House of Lords, on the $23^{\text {rd }}$ of June 2003, a number of members were also rather perturbed to learn that: "A French officer will not be liable to prosecution in the United Kingdom for an offence committed in the exercise of his functions in a control zone. A claim for compensation by, or against, such an officer will be subject to French law." (Baroness Scotland of Asthal, HL Deb 23 June 2003 vol 650 paragraph 90).

Others expressed unease about the impact of the Treaty on people seeking entry to the United Kingdom. Asylum advocates and some politicians were also worried about externalizing refugee responsibilities. For Labour Lord Avebury, for example, uncritical acceptance of juxtaposed controls undermined Britain's moral standing and the asylum process itself. "We on these Benches are concerned by some of the implications of juxtaposed controls which deal with the adequacy of a person's documentation rather than the merits of his claim" he asserted in a debate on June 23, 2003 (HL Deb 23 June 2003 vol. 650, Para. 95). "Many people talk about the pull factor of better conditions in the United Kingdom for asylum seekers," he went on,

'without at the same time underlining the fact that the conditions in France may not be as good as we would like them [to be].... That makes it all the more essential that we do not just stop up every means of entry to the UK for genuine asylum seekers, leaving the rest of Europe to look after them all, even those whose natural destination is Britain. Britain should also be taking a leading role in the development of a common European asylum policy, similar procedures for dealing with claims and comparable systems of support for asylum seekers. Only then will it be morally legitimate for us to extend juxtaposed controls, as we are doing under the order. (HL Deb 23 June 2003 vol. 650, Para 97) $)^{15}$

All such apprehensions were, however, efficiently dispatched. The French police already bore arms on British territory, Baroness Scotland remarked, and there was no need to be troubled about refugee rights. The Dublin system required France to

\footnotetext{
14 "Le traité du Touquet, même s'il n'est que bilatéral, est un premier pas vers une politique commune de l'Union, qui pour l'instant avance en ordre dispersé sur ces questions."

${ }^{15}$ https://api.parliament.uk/historic-hansard/lords/2003/jun/23/nationality-immigration-and-asylumact
} 
process asylum seekers on its territory and thus, the UK could move ahead with a clear conscience. ${ }^{16}$

In the years since this debate, and notwithstanding shifting patterns in relations with France, successive governments have remained wedded to the system of juxtaposed controls. In 2016, for example, then Minister for Europe David Liddington claimed that "The Le Touquet treaty is certainly vital to this country's border security." The reason he made clear, was simple: "Of the 100,000 people who have been prevented from entering the UK in the past five years, roughly a quarter were stopped at Calais at the juxtaposed controls." (HC, 26 February 2016, Volume 606).

In January 2018, France and Britain restated their joint commitment to this border control arrangement once again. The Sandhurst Treaty which updates Touquet, seeks both to speed up the processing of migrants in Northern France and to increase security provision at Calais. As set out in the 'Joint Action Plan' signed by the French Minister for the Interior and the British Home Secretary on 24 January 2019 this new arrangement "puts in place reinforced measures and resources to tackle illegal migration, in northern France and also in transit and source countries, as part of a whole-of-route approach." (Castaner and Javid, 2019: 1). In the by now familiar language of penal humanitarianism (xx, 2017; Lohne, 2018), this document sets out additional funding and support for criminal justice agencies in both territories to disrupt "serious criminal behaviour, disorder and the financial exploitation of vulnerable migrants" (Castaner and Javid, 2019: 1). The "success of the measures already taken to secure the principal ports and means of embarkation on the French coast", Castaner and Javid noted, had, unfortunately, spurred "illegal migrants and their criminal facilitators" to attempt to cross the Channel in small boats. This dangerous practice, their statement went on, not only places the lives of the 'illegal migrants' at risk, but also those who would seek to rescue them; it attracts greater numbers to France and the French North coast and, in short "threatens the integrity of the border control systems of the UK and France, which are vital in the fight against crime and terrorism." (Castaner and Javid, 2019: 1).

As these statements, and the funding they have released attest, border control at the French north coast remains high on the political agenda in Britain. Yet, there have been costs to this strategy. Most obviously it is expensive to offshore border control. As the numbers of people attempting to enter the UK began to rise, expenditure increased. In 2016, the French and British governments released a joint statement noting that a "total of 100 million euros have already been provided by British authorities to reinforce security" in Calais (Home Office, 2016; see also Cazeneuve and May, 2014). In 2018, under the terms of the Sandhurst Treaty, the British government agreed to a further payment of $£ 44.5$ million for fencing, CCTV and other detection technology in Calais and other Channel ports.

There have been other kinds of costs as well. In the summer months, for instance, media accounts are full of the negative impact of the stringent border controls on

\footnotetext{
${ }^{16}$ For a comparative account of the implications of the Dublin Treaty for asylum seekers in the UK and France see $x x$ et al, 2020.
} 
holiday-makers' travel and, more keenly, on business and trade (see for example UKBA, 2009). While the governments do little to placate vacationers, they are quick to respond to business concerns. Thus, when the Right-wing populist Calais mayor, Natacha Bouchart, threatened, in September 2014, to close her city's port, Britain, France and the EU responded swiftly and decisively. A new, EU-funded emergency accommodation centre, the Jules Ferry Centre, was opened, Ms Bouchart received a conciliatory visit from the French Interior Minister Bernard Cazeneuve and she was invited by the UK government to address the House of Commons Home Affairs Committee (Home Affairs committee, 2014; BBC, 2014, Nord Littoral, 2014).

For those who are stopped and detained in Calais or Dunkerque, the damages are, of course, highest of all. While their confinement itself is fleeting, whether in the British or French detention sites at this frontier, the impact of this form of administrative power on them and on the area around the ports is wide and deep. Consigned to precarious circumstances as they look for a means to enter Britain, men, women and children are forced into increasingly dangerous and illicit measures in their bid to live where they choose (Mohammadi, 2009; Hick and Mallet, 2019). Those living on the streets and in the camps of around Calais have reported violence at the hands of the French police (Human Rights Watch, 2015), while in October 2019, 39 people were found dead inside a refrigerated trailer which had travelled from France to Belgium to the UK, in a bid to evade border controls. In these tragic examples, we bear witness to how the uncoupling of territory and border control that juxtaposed controls signify, allows a far deeper articulation of sovereign power that prevents them from claiming a number of fundamental human rights.

In the next sections I turn to the detention sites and describe how they operate. Material was gathered from a variety of secondary sources and during my observations of the 2016 unannounced inspection conducted by HM Inspectorate of Prisons and their French counterparts the Contrôleur Général des Lieux de Privation de Liberté (CGLPL), in July 2016. ${ }^{17}$ This visit formed the basis for two joint reports by HMIP and CGLPL, on which I draw in the sections below (HMIP and CGLPL, 2016a; 2016b). It has been updated by ongoing research I began in August 2019. Although not sites of explicit border violence themselves, these institutions play an important role in shoring up the violence that inheres in the broader system of juxtaposed controls, which is designed to push people back, forcing them into dangerous and illegal forms of border crossing.

\section{Administrative Detention in Calais and Dunkerque}

There are currently three UK Short term holding facilities (STHFs) located in the Calais seaport and at the Coquelles Eurotunnel approach. There is one further STHF

\footnotetext{
${ }^{17}$ I would like to thank HMIP for the opportunity to visit these centres as an independent observer of their work. That visit was part of a longer collaboration about human rights monitoring (see, for example, xx et al, 2018). I would also like to thank Mitie for providing recent statistics about the French sites. The views expressed in this piece are mine and draw on a longer-term comparative research interest in British and French border control practices (see, for example, xx et al, 2016; 2020).
} 
in Dunkerque, just near the ferry terminal. ${ }^{18}$ All operate on Greenwich Mean Time. When staff step in the door, time goes back one hour; when their shift ends, they reenter the French time zone. All signs and paperwork, likewise, are in English; even in Dunkerque, where the staff are hired locally.

Information about daily life in these institutions is hard to come by. Other than intermittent reports produced by HMIP and CGLPL and even less frequent accounts from their counterparts in the office of the independent chief inspector of border and immigration (Vine, 2013), ${ }^{19}$ we have no information about any of these institutions. Unlike STHFs within the UK, these sites are not visited by the Independent Monitoring Board (IMB), even though they have requested access (IMB, 2018). As yet, no sustained academic research has been conducted in them. ${ }^{20}$ Civil Society initiatives in the UK, such as 'Unlocked' which gather and disseminate detainee testimonies from within Immigration Removal Centres, have not included people within these offshore sites. ${ }^{21}$ Likewise, while the nearby encampments have attracted an outpouring of volunteers, activism and legal challenge, as have the actions of the French police, these sites of administrative detention have escaped notice.

Indeed, these places are easy to overlook, located as they are, either near the freight lanes, for vehicles traveling to the UK by ferry or Eurotunnel, or situated out of sight behind the prefabricated building where immigration officers check passports for those heading to the Eurostar. The Dunkerque STHF occupies a small corner on the ground floor of an impressive stone building, so close to the ferry port that the smell of exhaust permeates it. Above, taking up the whole floor, are the offices of the Police Aux Frontières, and a 'zone d'attente pour personnes en instance', also known as a ZAPI (see for more detail, Anafe, 2013, and Makaremi, 2009)..$^{22}$ In sharp contrast to Mainwearing and Silverman's (2017) notion of detention-as-spectacle, in other

\footnotetext{
${ }^{18}$ In Dover, by contrast, where the French immigration authorities and border police operate under Juxtaposed controls, there is no French site of detention. Instead, the short-term holding facility in the port of Dover is run by the British and falls under the same rules as all the other STHFs in the UK (IMB, 2018).

${ }^{19}$ HMIP published their first report on these sites in 2006. There they refer to 'uncertainty about the application of UK or French law in respect of issues which might not be classified as being subject to immigration law, such as powers to use control and restraint or apply first aid.' (HMIP, 2006: 7). Such matters, it turned out, even applied to their own powers, as the lack of clarity over whose responsibility these places were to monitor led to a gap of 6 years before HMIP returned accompanied by their French counterparts, the Contrôleur Général des Lieux de Privation de Liberté (CGLPL). As their joint 2013 report notes in a characteristically neutral tone, "A lack of jurisdictional clarity meant that [these sites in France] could not be included in subsequent routine inspections by HMIP" (HMIP and CGPL, 2013: 5, emphasis added). During that visit, they record in a footnote that they were made aware by a staff member of another British STHF in French territory, three police cells in the British controlled area above Coquelles Tourist, and an entire holding facility at Dunkerque. The following year they published their first report on Dunkerque (HMIP and CGLPL, 2014).

${ }^{20}$ Although at the time of writing, I have recently begun a large-scale multi-year project on escorting and deportation which will include these STHFs along with others in the UK.

${ }^{21}$ See for example, https://unlocked.org.uk.

${ }^{22}$ During the monitoring visit this site held over ten men lying on mattresses on the floor in a glass enclosed cell.
} 
words, the holding centres in France are practically invisible, hidden within the layers of security around the ports in which they are located, difficult to find, even when you know what you are looking for.

According to HMIP and CGLPL, in 2016, Coquelles Tourist was the busiest of the four STHFs, processing around 240 detainees per month. It was followed by Dunkerque which had housed 548 detainees over the past three months (i.e. approximately 183 per month), including 111 children, of whom 26 had been unaccompanied by an adult (HMIP and CGPL, 2016b: 10). Next was Calais Tourist, which held 133 per month and finally, Coquelles Freight reported approximately 64 detainees per month (HMIP and CGLPL, 2016a). In each site, the period of detention was brief, lasting between $3-5$ hours. The longest detention which had occurred in Dunkerque, was recorded as 13 and a half hours.

Together, however inexactly, these figures suggest that, in 2016, about 20 people were detained across these four sites per day, for a few hours at a time. Though double the sums recorded in earlier visits by the monitors (CGLP, 2012; 2014), these figures pale in comparison to the population of the Calais camp, which, before it was razed to the ground that year, housed as many as 10,000 men, women and children, nearly all of whom sought entry to Britain (Hicks and Mallet, 2019). According to more recent numbers provided by Mitie in October 2019, they have remained steady. ${ }^{23}$

The STHFs in France hold people heading towards the UK who have been identified by the UK Border Force or by private security staff checking freight, coaches, cars and foot passengers. Detainees are held on an IS91 form, the same document which expresses the authority to detain on British soil. Some of those who are confined have attempted to enter the UK by hiding in vehicles. Others have been stopped for further questioning by UK immigration officers after presenting themselves at the entry point. In Calais, truck drivers suspected of facilitating irregular migration (e.g. by concealing people within their trailers) may be detained by the British, whereas in Dunkerque, they are usually handed directly to the PAF for criminal investigation.

The STHFs in France, as they are in the UK, are staffed by Detainee Custody officers (DCOs) who are employed by private sector firms. At the time of writing, those in Calais and Coquelles are British citizens employed by Mitie. In May 2018 this company took over from Reliance Secure Task Management, ${ }^{24}$ better known as

\footnotetext{
${ }^{23}$ From October 2018 - 2019, Calais had an average of 155 detentions a month, Coquelles tourist 229 and Coquelles Freight, 68. The "vast majority" were held for less than 8 hours (Personal correspondence).

${ }^{24}$ According to Corporate Watch (2014), "Reliance Secure Task Management (RSTM), part of Kingham's group of private security companies, started detaining and deporting asylum-seekers for the Home Office in May 2011, taking over the job from G4S. The four-year government contract was worth around $f 120 \mathrm{~m}$." The company was bought the following year by the Capita Group, who, later that same year signed a 4-year contract with the Home Office "to trace and contact overstayers and assist them in removing the barriers to their return to their home countries." (http://www.capita.co.uk/news-and-opinion/news/2012/julydec/capita-signs-contract-withukba.aspx\#sthash.Ocvpfx6x.dpuf).
} 
Tascor, who ran the centres when I visited in $2016 .{ }^{25}$ Then and now, these officers are either bussed in daily across the channel from their homes in Kent, or they reside four nights a week in a cheap hotel in Calais. Dunkerque, by contrast, despite being a British STHF, is run by French staff, most of whom live locally. They work for Eamus Cork Solutions (ECS), a private security firm registered in France. ${ }^{26}$

All STHFs are overseen by local UK Border Force personnel, who visit daily. As with the British DCOs, these government officials are either bussed in, or put up during the week in a hotel. Legally, they authorize detention and monitor its length and conditions. They may be deployed across any of the sites in the juxtaposed control area.

When the Home Office finally published the STHF rules in 2018 , they made it clear that the sites on French soil did not fall under them, since they are governed by the Treaty of Touquet (Home Office, 2018: 5). Yet, the, Home Office noted, they should nonetheless follow the "spirit" of these rules (Home Office, 2018: 5). As such, normally, detainees will not be held for more than 24 hours. Indeed, most are only held for a few hours, before being handed over to the PAF. The centres are closed on Christmas Day.

Detainees are brought to the STHFs either by PAF agents, or by private security officers working for Eamus Cork Solutions (ECS) in the freight lanes, whose job is to locate people concealed in the vehicles. These officers are not allowed to board the trucks to avoid injury from the cargo among which people hide. Instead, they must persuade those who are detected, either through visual inspections, sniffer dogs, or by equipment including heartbeat monitors, carbon dioxide detectors and scanners, to give themselves up. Once they emerge from their hiding place, these people are transferred to a van, and driven either to the UK-run detention site in Coquelles Freight, or directly to the French border police who often simply transfer them to the edge of the Calais ferry terminal, where, presumably, they may try the voyage again. The following paragraph from the 2016 report from HMIP and CGPL (2016a: 15) describes how this process works:
"During our inspection, four young Iraqis were found in the rear of a refrigerated lorry in a temperature of about -20 degrees centigrade. Border Force got the young men out of the lorry quickly and wrapped them in foil blankets. Tascor transferred the men to Border Force offices where they were interviewed briefly by officers from Kent police. Tascor then transferred the men to PAF. A family of three adults and four children were found later

\footnotetext{
${ }^{25}$ Along with all 30 of the UK-based Short term holding facilities and the two short-term residential centres in Belfast and Manchester, the Calais STHFs are part of the ten-year contract Mitie won which also includes in-country escorts, deportations and removals.

${ }^{26}$ According to their website, "The Eamus Cork Group offers solutions to all problems affecting the safety and security of industrial sites, private and public transport systems, large work sites, the most strategic infrastructures of international companies or government buildings and also for their personnel who are the most at risk to nuisances and various threats." (http://www.eamuscork.com).
} 
the same day hidden in a different lorry. Tascor transferred the family from the freight lanes to the facility using a child seat for the youngest child. The family waited outside the facility for a short time until PAF were ready to see the family. The van door was opened and DCOs gave the family sandwiches and drinks. They were allowed to get off the van to stretch their legs and use the toilet in the facility. The family waited outside the facility for about 15 minutes before being transferred to the PAF."

Internally, the detention units are small and unremarkable (see for instance, the photographs in HMIP and CGLPL, 2016a; 2016b). With their rows of chairs, aging information posters, books and magazines they resemble any other waiting room, until you notice the chairs are bolted to the floor. In 2016, the Calais Tourist site had recently been refurbished. It included a separate 'family room', with soft chairs, a purple vinyl bean bag and bright decorations on the walls, to make it less stressful for children. At the time of the 2016 monitoring visit, this room lay empty (HMIP and CGLPL, 2016a: 24). Other than a few out of date magazines and unlikely books, STHFs offer no activities other than some puzzles and games for children and religious texts. Anyone who wishes to smoke, has to hope for a sympathetic officer who might briefly accompany them outside.

In 2016, detainees were offered mass-produced supermarket sandwiches, brought over from Britain. In Coquelles Tourist, there was a basket filled with packets of crisps and packaged foods left out on a table for snacking. Hot meals were generally not available, although some of the sites showed the inspection team that they could offer microwaved dinners. Under Mitie, some of the food has changed; jam and cream filled croissants have replaced sandwiches; "they have a longer shelf-life and cause less mess", an officer asserted. In addition to microwave curries, holding facilities, in France as in the UK, now offer a selection of ramen noodles.

Most crucially, then and now, British detention sites in Northern France provide no onsite medical care, nor access to legal advice. There is no nurse or doctor on duty, nor any who can be easily contacted. Staff are not allowed to administer medicine, nor are detainees allowed to take any of their medication into the holding room with them; it must remain packed away in their luggage. In the case of a health crisis, or indeed if someone simply needs to take a paracetamol for a headache, staff have to call the local emergency services to administer the medication. In 2016, HMIP and CGLPL (2016a: 7; 23) noted uneasily, "No information was displayed on detainees' legal rights," in any of the facilities visited, nor was information offered about how to claim asylum. In this final example, the potentiality of these sites is made concrete, as notwithstanding the monitor's recommendation that "Independent legal advice from French organisations should be available to detainees." (HMIP and CGPL, 2016a; 23; 2016b: 11), the location of these sites of detention within an area governed by juxtaposed controls renders such a demand impossible to meet. These institutions are, for legal purposes, on British soil; the lack of French legal advice is no accident, it is part of their design. 


\section{Conclusion: Administrative Power and the Banality of Border Control}

The short-term holding facilities in Northern France I have described in this paper are part of a wider set of border control structures and practices that differentiate between those seeking to enter the UK. For those fleeing conflict and persecution in their homeland, who, since the war in the Balkans in the 1990s, have gathered in Calais hoping to find a way across the border to join friends and relatives in Britain, these banal sites of administrative custody embody the custodial potential and punitive nature inherent within the Common European Asylum Framework (BasilienGainche, 2015; Costello and Mouzourakis, 2015). In their institutional reliance on the PAF, both to deliver and remove their occupants, these places of administrative custody offer concrete examples of the hollowing out of humanitarian protections and the erosion of legal distinctions between the asylum and detention systems as well as the increasing interconnections between immigration control and criminal justice (van der Woude and van der Leun, 2017).

As these systems merge and meld, such places suggest, rights give way to administrative convenience. Here, their invisibility and banality, as Alison Mountz has observed about island detention, is the point (Mountz, 2015). In them, the person is stripped away, leaving only process, which, in any case, always occurs elsewhere, in the office of the PAF or with UK Border Force. Rather than states of exception, these are better conceived of as 'abject spaces', (Isin and Rygiel, 2007: 184), whose occupants are treated 'neither as subjects (of discipline) nor objects (of elimination) but as those without presence'.

Without rights, without process, and without people what kind of border do these institutions enforce? Who is responsible for it and how might we hold them to account? It is in these final set of questions where these sites of border detention are most troubling. For, in contrast to the visible border spectacle, which, in its public articulation of violence, requires effort and justification, these banal sites of administrative custody, which both help secure the border and justify it, evade scrutiny and critique. The implications of that should concern us all. 


\section{References}

Aas, K.F. (2013). 'The Ordered and the Bordered State: Migration Control, Citizenship, and the Northern Penal State.' In KF Aas and M Bosworth (Eds.). The Borders of Punishment: Migration, Citizenship, and Social Exclusion. Oxford: Oxford University Press.

Agamben, G. (2005). State of Exception. Chicago: University of Chicago Press.

Agreement between the Government of the United Kingdom of Great Britain and Northern Ireland and the Government of the French Republic concerning the Carrying of Service Weapons by the Officers of the UK Border Agency on French Territory in Application of the Treaty concerning the Implementation of the Frontier Controls at the Sea Ports of Both Countries on the Channel and North Sea. Treaty Series No. 21. 2011. Paris, 24 May, 2011. CM 8117. London: HMSO.

Anafe. (2013). Guide theorique et pratique: La procedure en zones d'attente Available at: https://www.infomie.net/IMG/pdf/Guide anafe web-1.pdf. Accessed 25 July 2019.

Andersson, R. (2014). Illigality, Inc. Clandestine Migration and the Business of Bordering Europe. Berkeley, CA: University of California Press.

Aradau, C., and Tobias, B. (2010) 'Governing circulation. A critique of the biopolitics of security.' In de Larrinaga, M., and M.G. Doucet. (Eds.) Security and Global Governmentality: Globalization, Governance and the State. London: Routledge.

Assemblée Nationale, Rapport 16 Dec. 2003

Audit, M. (2008). 'The Channel Tunnel Group Ltd and France: Manche SA v United Kingdom and France, Partial Award on Jurisdiction, Decision of 30 January 2007', The International and Comparative Law Quarterly. 57(3): 724 - 732.

Babels Collectif. (2017). De Lesbos à Calais: Comment l'Europe fabrique des camps. Le Passager Clandestin.

Barbero, I. (2018). 'The European Union Never got Rid of Its Internal Controls: A Case Atudy of Detention and Readmission on the French-Spanish Border,' European Journal of Migration and Law. 20(1): 1- 27.

Barker, V. (2017). Nordic Nationalism and Penal Order: Walling the Welfare State. Abingdon: Routledge.

Basilien-Gainche, M.L. (2015). 'Immigration Detention under the Return Directive: The CJEU Shadowed Lights,' European Journal of Migration and Law, 17(1): 104. 
BBC (2014). 'Calais mayor warns of blockade over migration.' BBC News Online, 3 September 2014. Available at: http://www.bbc.co.uk/news/world-europe-29041621

Bhatia, M. (2018). 'Social death: the (white) racial framing of the Calais 'jungle' and 'illegal' migrants in the British tabloids and right-wing press,' in Bhatia, M. Poynting, S., and W. Tufail. (Eds.). Media, Crime and Racism. London: Palgrave. pp. $181-212$.

Bloom, T., and Risse, V. (2014). 'Examining Hidden Coercion at State Borders: Why Carrier Sanctions Cannot Be Justified', Ethics \& Global Politics. 7(2): 65 - 82.

Brown, W. (2010). Walled States, Waning Sovereignty. New York: Zed Books.

Castaner, C. and Javid, S. (2019). 'Joint action plan by the UK and France on combating illegal migration involving small boats in the English Channel.' Available at:

https://assets.publishing.service.gov.uk/government/uploads/system/uploads/attac hment data/file/773403/UK France declaration 24 Jan 13.00.pdf. Last accessed July 28, 2019.

Cazeneuve, B and May, T. (2014). 'France and UK agree steps to combat illegal migration.' http://www.ambafrance-uk.org/France-and-UK-agree-steps-to

Cazeneuve, B., and May, T. (2015). 'Managing Migratory Flows in Calais: Joint Ministerial Declaration on UK/French Co-Operation,' Available: https://assets.publishing.service.gov.uk/government/uploads/system/uploads/attac hment data/file/455162/Joint declaration 20 August 2015.pdf. Last accessed 19 September 2018.

Clayton, G. (2010) 'The UK and Extraterritorial Immigration Control.' In B. Ryan and V. Mitsilegas (Eds.) Extraterritorial Immigration Control: Legal Challenges. Leiden: Martinus Nijhoff Press, pp. $397-430$.

Corporate Watch. (2014). Rival firms fight over deportation dividend. 5 September 2014. Available at: http://www.corporatewatch.org/news/2014/sep/05/rival-firmsfight-over-deportation-dividend. Accessed 16 March 2015.

Costello, C., and Mouzourakis, M. (2016). 'EU Law and the Detainability of AsylumSeekers,' Refugee Survey Quarterly, 1(1): 47 - 73.

Foucault, M. (2009). Security, Territory, Population: Lectures at the College de France, 1977- 1978. London: Penguin.

Foucault, M. (2004). Society Must be Defended: Lectures at the College de France, 1975-76. London: Penguin.

Franko, K. (2014). 'Bordered penality: Precarious membership and abnormal justice.' Punishment \& Society. 16(5): 520 - 541. 
De Genova, N. (2013). 'Spectacles of migrant 'illegality': the scene of exclusion, the obscene of inclusion,' Ethnic and Racial Studies. 36(7): 1180 - 1198.

De Genova, N. (2002). Migrant "illegality" and deportability in everyday life. Annual Review of Anthropology, 31: 419-47.

Gibney, M. (2006). 'A Thousand Little Guantanamos: Western States and Measures to Prevent the Arrival of Refugees,' in K. Tunstall. (Ed.). Displacement, Asylum, Migration: The Oxford Amnesty Lectures 2004. Oxford: Oxford University Press. pp. 139-169.

Gundhus, H. I. \& Franko, K. (2016). 'Global policing and mobility: Identity, territory, sovereignty', In B. Bradford, Be. Jauregui, I. Loader \& J. Steinberg (Eds.), Sage Handbook of Global Policing. London: Sage Publications. pp. $497-514$.

Hicks, D., and S. Mallett. (2019). Lande: The Calais Jungle and Beyond. Bristol: Bristol University Press.

HMIP (2014). Report on an unannounced inspection by HMIP of the short-term holding facility at Dunkerque, 28 January 2014. London: HMIP.

HMIP (2006). Report on the unannounced inspections of three French non-residential, short-term holding facilities at Calais Seaport, Coquelles Freight and Coquelles Tourist, 2-3 August 2005. London: HMIP.

HMIP \& CGLPL (2016a). Report on unannounced inspections of the UK Short-term holding facilities at Coquelles and Calais by HM Chief Inspector of Prisons accompanied by the Contrôleur Général des Lieux de Privation de Liberté. London: HMIP.

HMIP \& CGLPL (2016b). Report on unannounced inspections of the UK non-residential Short-term holding facilities at Dunkerque, France by HM Chief Inspector of Prisons accompanied by the Contrôleur Général des Lieux de Privation de Liberté. London: HMIP.

HMIP \& CGLPL (2013). Report on unannounced joint inspections of Coquelles and Calais non-residential short-term holding facilities. 6- 7 November 2012 by HM Chief Inspector of Prisons and Contrôleur Général des Lieux de Privation de Liberté. London: HMIP.

Home Affairs Committee (2016). House of Commons Home Affairs Committee, Migration Crisis: Seventh Report of Session 2016-2017, HC 24. London: House of Commons.

Home Affairs Committee (2015). House of Commons Home Affairs Committee, The Work of the Immigration Directorates: Calais. Eighteenth Report of Session 2014 - 
15, HC 902. London: House of Commons.

Home Affairs Committee (2014). Oral Evidence: The Work of the Immigration Directorates 2014 Q2, Tuesday 28 October 2014.

Home Office (2016). "Joint statement by the governments of France and the United Kingdom," Press Release. 30 August, 2016. Available at: https://www.gov.uk/government/news/joint-statement-by-the-governments-offrance-and-the-united-kingdom

Ibrahim, Y., and Howarth, A. (2018). Calais and it Border Politics: From Control to Demolition. Abingdon: Routledge.

Isin, E. and K. Rygiel (2007). 'Abject Spaces: Frontiers, Zones, Camps in E. Dauphinee and C. Masters (eds). The Logic of Biopower and the War on Terror. Basingstoke: Palgrave. pp. $181-203$.

IMB (2018). The Annual Report of the Independent Monitoring Board at Port of Dover Short Term Holding Facility for the reporting year 2017, Published May 2018.

London: IMB.

Jones, R. (2017). Violent Borders: Refugees and the Right to Move. London: Verso.

Katz, C. (2007). "Banal Terrorism." In D. Gregory \& A. Pred. (Eds.). Violent Geographies, New York: Routledge. pp. 349-61.

Lohne, K. (2018). 'Penal humanitarianism beyond the nation state: An analysis of international criminal justice'. Online First. Theoretical Criminology. https://doi.org/10.1177/1362480618806917

Makaremi, C. (2009). 'Governing Borders in France: From Extraterritorial to Humanitarian Confinement,' Canadian Journal of Law \& Society. 24(3): $411-432$.

Mainwearing, C., and Silverman, S. (2017), 'Detention-as-Spectacle', International Political Sociology, 11: $21-38$.

Mohammadi, W. (2009). De Kaboul à Calais: L'incroyable périple d'un jeune Afghan. Temoignage.

Mountz, A. (2015). 'In/visibility and the Securitization of Migration Shaping Publics through Border Enforcement on Islands.' Cultural Politics 11: 184-200.

Mountz, A. (2011). 'The enforcement archipelago: Detention, haunting and asylum on islands.' Political Geography. 30: $118-128$.

Nord Litteral (2014). 'Cazeneuve-Bouchart: un premier terrain d'entente', Nord Litteral, 4 November 2014.2 Available 
http://www.nordlittoral.fr/accueil/cazeneuve-bouchart-un-premier-terrain-dentente-iaOb0n152539

Ryan B. (2004). 'The European Dimension to British Border Control', Journal of Immigration, Asylum and Nationality Law, 18(1): 6 - 16.

Sanchez, G. (2016). Human Smuggling and Border Crossing. Abingdon: Routledge.

Schuster, L. (2003). 'Asylum seekers, Sangatte and the Tunnel'. Parliamentary Affairs. 56(3): $506-522$.

Treaty between the Government of the United Kingdom and the Government of the French Republic concerning the implementation of frontier controls at sea ports of both countries on the Channel and North Sea. Le Touquet, 4 February, 2003. Treaty Series no. 18. Cm 5832. London: HMSO.

Treaty between the Government of the United Kingdom and the Government of the French Republic concerning the reinforcement of cooperation for the coordinated management of their shared border. Sandhurst, 1 February, 2018. Cm 9568.

UKBA (2010). Service Level Agreement between UK Border Agency CHANNEL TUNNEL (Coquelles \& Cheriton) and The Operator EUROTUNNEL version 2. Signed 15 July 2010. Available

at: https://www.whatdotheyknow.com/request/63425/response/168575/attach/4/UKB A\%20SLA\%20Coquelles\%202010\%20SLA\%202011.03.25.pdf

Vine, J. (2013). An Inspection of Juxtaposed Controls. London: ICIBI. Available at: https://assets.publishing.service.gov.uk/government/uploads/system/uploads/attac hment data/file/546809/An-Inspection-of-Juxtaposed-Controls Aug 2013.pdf. Last accessed 30 July 2019.

Vrabiescu, I. (2019). 'Devised to punish: Policing, detaining and deporting Romanians from France', European Journal of Criminology. Online First.

van de Woude, M. (2018). 'Border Policing in Europe and Beyond', in M. Boer. (Ed.). Comparative Policing from a Legal Perspective. London: Edward Elgar. pp. 255 - 271.

van der Woude, M., and J. Van de Leun. (2017). 'Crimmigration Checks in the Internal Border of the EU: Finding Discretion that Matters', European Journal of Criminology. 14(1): $27-45$.

Walters W. (2015) "Reflections on Migration and Governmentality". Movements. Journal für kritische Migrations- und Grenzregimeforschung 1: 1-30.

Walters, W. (2002). 'Mapping Schengenland: Denaturalizing the Border', Environment and Planning D: Society and Space. 20(5): 561 - 580.

Yuval-Davis, N, Wemuss, G and K. Cassidy. (2019). Bordering. Cambridge: Polity. 
xx, , et al. (in press. 2020)

Xx et al, (2018).

Xx, 2017

Xx 2014

Xx et al 2016

Xx, 2019 